\title{
The Early Nodulin Gene ENOD2 Shows Different Expression Patterns During Sesbania rostrata Stem Nodule Development
}

\author{
Sofie Goormachtig, Marc Van Montagu, and Marcelle Holsters \\ Laboratorium voor Genetica, Departement Genetica, Vlaams Interuniversitair Instituut voor Biotechnologie \\ (VIB), Universiteit Gent, K.L. Ledeganckstraat 35, B-9000 Gent, Belgium \\ Accepted 18 November 1997.
}

\begin{abstract}
During nodule development on stems of Sesbania rostrata, the ENOD2 gene was expressed in the nodule parenchyma and in outer cortical cells. The latter, novel expression pattern was low in uninfected nodulation sites, strongly enhanced 1 day after infection, and correlated with young peridermal cells at later stages. The induction of both ENOD2 transcript accumulation patterns was dependent on Nod factor-producing bacteria.
\end{abstract}

Specific recognition between rhizobia (bacteria belonging to the genera Rhizobium, Azorhizobium, Bradyrhizobium, or Sinorhizobium) and compatible legume hosts leads to the formation of root nodules, inside of which symbiotic forms of the bacteria, the bacteroids, fix molecular dinitrogen. Concerning the early recognition, it is now well established that flavonoids, secreted by the legume roots, induce the bacterial nod genes and that Nod proteins are involved in the production and secretion of the Nod factors, the morphogenetic compounds that trigger the plant program for nodule formation (Long 1996). Plant genes that are expressed before the onset of nitrogen fixation are called early nodulin genes (ENOD) (van Kammen 1984; Franssen et al. 1992). For several of these $E N O D$ genes, the expression pattern is well characterized and, although their exact function is usually not known, these genes can be used as molecular markers to study various aspects of the nodulation. The early nodulin gene ENOD2, first isolated from soybean, is such a widely used marker. It codes for a proline-rich protein with two repeating pentapeptide motifs and a putative signal peptide, suggesting that ENOD2 is located in the cell wall (Franssen et al. 1987, 1989). In situ hybridizations revealed that the ENOD2 gene is expressed in the nodule parenchyma of determinate and indeterminate nodules (Van de Wiel et al. 1990; Allen et al. 1991). We are studying the early molecular events in the interaction between the tropical legume Sesbania rostrata and the microsymbiont Azorhizobium caulinodans. Typical for this symbiosis is that nodules are also formed on the stem, at positions of dormant root primordia.

Corresponding author: M. Holsters; Fax 32-9-2645349

E-mail: mahol@gengenp.rug.ac.be
The development of the $S$. rostrata stem nodules was studied intensively by various microscopical techniques (Tsien et al. 1983; Duhoux 1984) and, recently, by the use of molecular markers for cell division (Goormachtig et al. 1997). The rhizobia penetrate the plant via the fissure that is created by protrusion of the incipient root through the stem cortex. The bacteria are guided via inter- and intracellular infection threads toward the nodule primordia, which are formed in the midcortex of the root primordium. The nodule development is characterized by a proximal-to-distal differentiation, as also seen for indeterminate nodules (Goormachtig et al. 1997). However, about 1 week after infection, the meristematic activity disappears and differentiation is terminated, resulting in typical, round-shaped, determinate nodules.

Two ENOD2 cDNAs and one gene (SrEnod2) were cloned from $S$. rostrata (Strittmatter et al. 1989; Dehio and de Bruijn 1992). Studies in transgenic Lotus showed that the 3' untranslated region is important to cause SrEnod2 transcript accumulation in the nodule parenchyma (Chen and de Bruijn 1995). After application of cytokinins, ENOD2 transcripts accumulate in $S$. rostrata roots in a time- and concentrationdependent manner (Dehio and de Bruijn 1992). Evidence was obtained that the cytokinin effect is a post-transcriptional event (Silver et al. 1996).

The expression pattern of ENOD2 during the development of stem-borne nodules on $S$. rostrata was revealed by in situ hybridizations with the procedures described before (Goormachtig et al. 1997). Sections of uninfected root primordia and root primordia at several stages after infection with Azorhizobium caulinodans ORS571 were hybridized with a SrEnod2 sense and antisense RNA probe, stained with toluidine blue, and analyzed by light microscopy, with bright-field and dark-field optics (Figs. 1 and 2). The antisense and sense RNA probes were made by digesting pSrEnod2 (pBluescript $\mathrm{KS}^{-}$containing a 1,240-bp fragment of the SrEnod2 gene from position -381 to +968) (Dehio and de Bruijn 1992) with HindIII and BamHI, respectively. Control hybridizations with the sense probe did not give signal above background (data not shown).

In uninfected root primordia, low transcript levels were detected in some cells of the outer cortex (Fig. 1A and B, arrowheads). After bacterial inoculation, this expression was en- 
hanced (Fig. 1C and E). The cells containing ENOD2 transcripts were highly vacuolated and slightly larger than their neighboring cortical cells (Fig. 1D, arrow), whereas on the exterior side, they were often flanked by cells containing suberin or cutin in their walls (intensely blue-stained cell walls; Fig. 1D, triangles). Parenchymatous cells around the connection of the vascular bundle of the incipient root and of the stem also contained ENOD2 transcripts (Fig. 1A, double arrowhead). These new ENOD2 expression patterns are somehow surprising but explain the low expression level de- tected by RNA blot hybridization in uninfected root primordia (Goormachtig et al. 1995) and the rapid induction of ENOD2 at day 1 after bacterial inoculation (Goormachtig et al. 1995). The latter observation could not be due to the expression in the nodule parenchyma because this tissue only started to differentiate at day 3 after infection (see below). During further stages of development, ENOD2 transcripts were still found in exterior cells (Figs. 1F, G, I, J, and 2A and B). High magnification (Fig. 2C) revealed that ENOD2 was expressed in the youngest, still living, peridermal cells, closest to the secon-
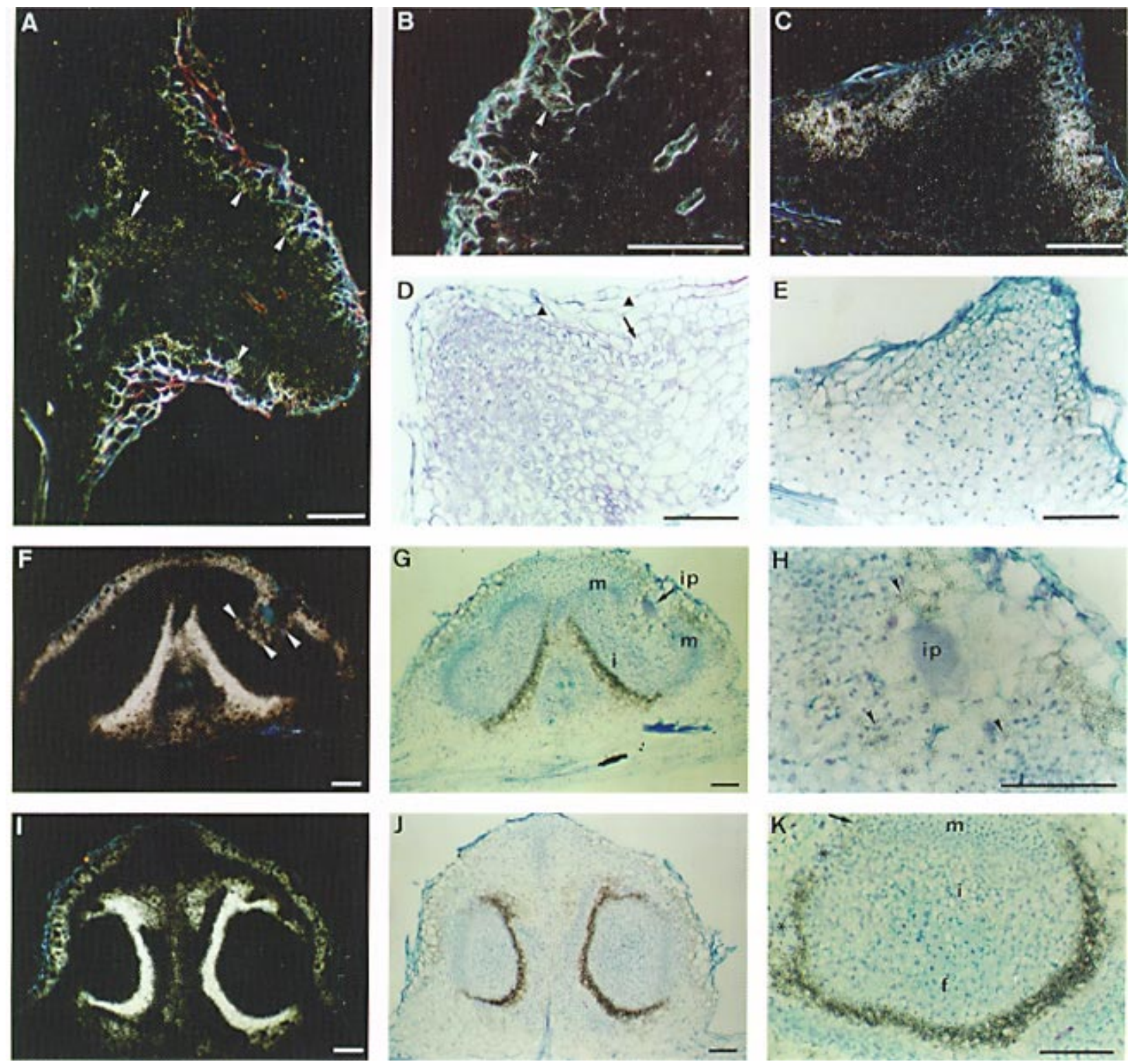

Fig. 1. In situ localization of ENOD2. A-C, E-K, Longitudinal sections $(10 \mu \mathrm{m})$ through uninfected root primordia and developing nodules hybridized with a ${ }^{35}$ S-labeled ENOD2 antisense probe. A-B, Dark-field micrograph of an uninfected root primordium. Arrowheads indicate exterior cells expressing $E N O D 2$ whereas double arrowhead points to ENOD2 containing parenchymatous cells around connection between vascular bundle of the stem and of the incipient root. B, Enlargement of A. C and E, Dark- and bright-field micrographs, respectively, of a root primordium, 1 day after bacterial infection. D, Semithin, toluidine blue-stained section of a Technovit-embedded root primordium, 1 day after infection. Arrow indicates cells that correspond to the cells in $\mathbf{E}$ that contain ENOD2. Triangles indicate cells with suberized cell walls. F and $\mathbf{G}$, Dark- and bright-field, respectively, of a developing nodule, 3 days after bacterial infection. H, Enlargement of $\mathbf{G}$. Arrowheads in $\mathbf{F}$ and $\mathbf{H}$ indicate cells around infection pockets that express ENOD2. I and J, Darkand bright-field micrographs, respectively, of a developing nodule, 4 days after infection. $\mathbf{K}$, Enlargement of $\mathbf{J}$. Arrow indicates youngest cells expressing ENOD2. Asterisks indicate vascular bundles of developing nodule that do not contain ENOD2 transcripts. Abbreviations: f, fixation zone; i, invasion zone; ip, infection pocket; $\mathrm{m}$, meristem. Bar $=100 \mu \mathrm{m}$. 
dary meristem from which they are derived. It cannot be defined unambiguously whether the secondary meristem also showed ENOD2 expression. ENOD2 was also expressed in interior cortical cells flanking infection pockets (Fig. 1F, G, and $\mathrm{H}$, arrowheads). The expression in the peridermal cells faded out as nodulation progressed. The absence of ENOD2 in peridermal cells of mature 20-day-old nodules (Fig. 2D) corresponded to the complete maturation of the periderm, only consisting of dead cells with highly suberized walls.

Nodule primordia were clearly visible in the mid-cortex of the root primordium 2 days after infection (Goormachtig et al. 1997). From 3 days after infection on, the nodule primordia started to differentiate (Goormachtig et al. 1997). In situ localization revealed that, at this stage, ENOD2 was expressed in some peripheral cell layers of the proximal part of the developing nodule, near the root stele (Fig. $1 \mathrm{~F}$ and G). Also, the central tissue differentiation started in the most proximal part of the nodule primordium (Goormachtig et al. 1997). No ex- pression of ENOD2 was seen in cells peripheral to the nodule meristematic cells (Fig. 1F and G). Further stages of nodule differentiation were characterized by the coexistence of different developmental zones: a distal meristem, an invasion zone, and a fixation zone (Goormachtig et al. 1997). As nodulation progressed, the meristem and invasion zone were restricted to a few distally located cell layers whereas the fixation zone enlarged (Goormachtig et al. 1997). As seen in Figure $1 \mathrm{I}$ and $\mathrm{J}$, the expression of ENOD2 in exterior cell layers of the developing nodule progressed in a distal direction, following the meristem. A magnification of Figure $1 \mathrm{~J}$ demonstrates that ENOD2-containing cells were derived from the nodule meristem (Fig. 1K, arrow). Cells that will become nodule vascular tissue do not contain ENOD2 transcripts (Fig. 1K, asterisks). When meristematic activity disappeared (between 6 and 8 days after infection) and differentiation was completed, the nodule parenchyma and concomitant ENOD2 expression completely surrounded the central tissue
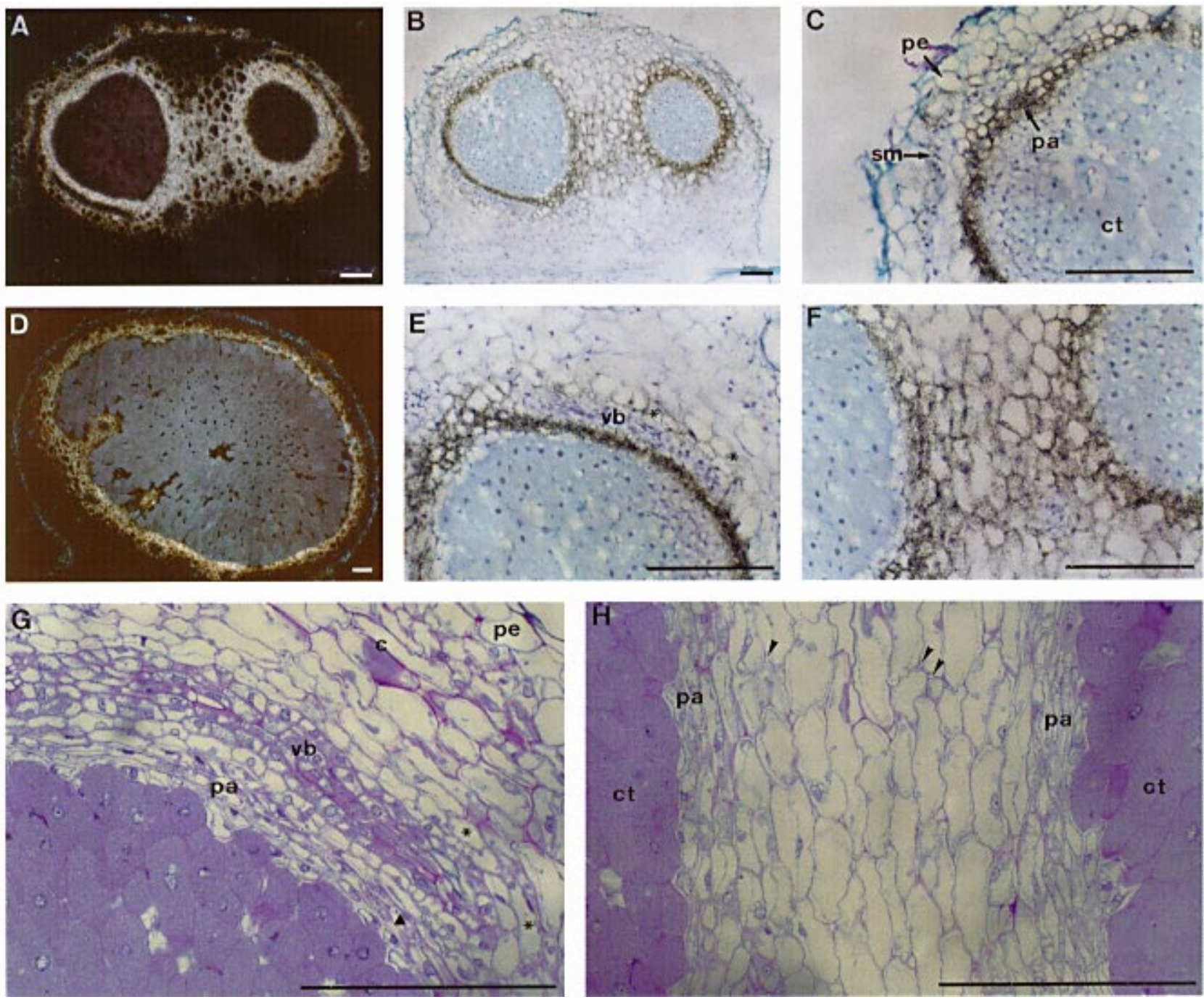

Fig. 2. In situ localization of $E N O D 2$. A-F, Longitudinal sections $(10 \mu \mathrm{m})$ through nodules hybridized with a ${ }^{35}$ S-labeled $E N O D 2$ antisense probe. A and B, Dark- and bright-field, respectively, of a young nodule, 7 days after infection. C, E, and F, Magnifications of B. D, Dark-field micrograph of a mature, 20-day-old nodule. $\mathbf{G}$ and $\mathbf{H}$, Semithin, toluidine blue-stained sections of a Technovit-embedded nodule 7 days after infection, corresponding to the regions shown in $\mathbf{E}$ and $\mathbf{F}$, respectively. Asterisks in $\mathbf{E}$ and $\mathbf{G}$ indicate cortical cells surrounding the nodule vascular bundle that contain ENOD2 transcripts. Triangle in $\mathbf{G}$ indicates the small cells of the nodule parenchyma. Arrows in $\mathbf{H}$ indicate large intercellular spaces. Abbreviations: c, cortex; ct, central tissue; pa, nodule parenchyma; pe, periderm; sm, secondary meristem; vb, vascular bundle. Bar $=100 \mu \mathrm{m}$. 
(Fig. 2A and B). Finally, in mature nodules (20 days after infection), ENOD2 transcripts were still detected, albeit at a lower level (Fig. 2D). Similar ENOD2 expression patterns were observed in pea, soybean, and alfalfa nodule development (Van de Wiel et al. 1990; Allen et al. 1991). However, due to the presence of the persistent meristem, ENOD2 expression never completely surrounded the central tissue of the pea and alfalfa nodules (Van de Wiel et al. 1990; Allen et al. 1991).

ENOD2 transcripts were most abundant in three layers of small, densely packed cells positioned directly next to the central tissue, but they were also present in some adjacent larger cells. This is particularly clear around nodule vascular bundles (Fig. 2E and G): small, densely packed cells are lying between the central tissue and the vascular bundle (Fig. 2G, triangle). At the exterior side, the vascular bundle is bordered by slightly larger cells, evenly containing ENOD2 transcripts (Fig. 2E and G, asterisks).

During stem nodule development, usually several nodule primordia are induced in one dormant root primordium, leading to one continuous ring of central tissue or to different nodule lobes, depending on the eventual coalescence of the nodule primordia (Goormachtig et al. 1997). Cortical cells inbetween different nodule lobes also contained ENOD2 transcripts (Fig. 2F). This region consisted of large cells with sometimes large intercellular spaces (Fig. 2H, arrows).

To test whether the observed ENOD2 expression patterns are correlated to nodulation, RNA levels were compared after wild-type infection or infection with two different mutant strains. The strain ORS571-V44 is mutated in nodA and is therefore unable to produce Nod factors (Van den Eede et al. 1987; Mergaert et al. 1993). The second strain, ORS571-X15, is mutated in a gene, which is implicated in surface polysaccharide production (Goethals et al. 1994), and is not able to invade the plant, but does produce Nod factors (W. D'Haeze and M. Holsters, unpublished results). Application of the lat-
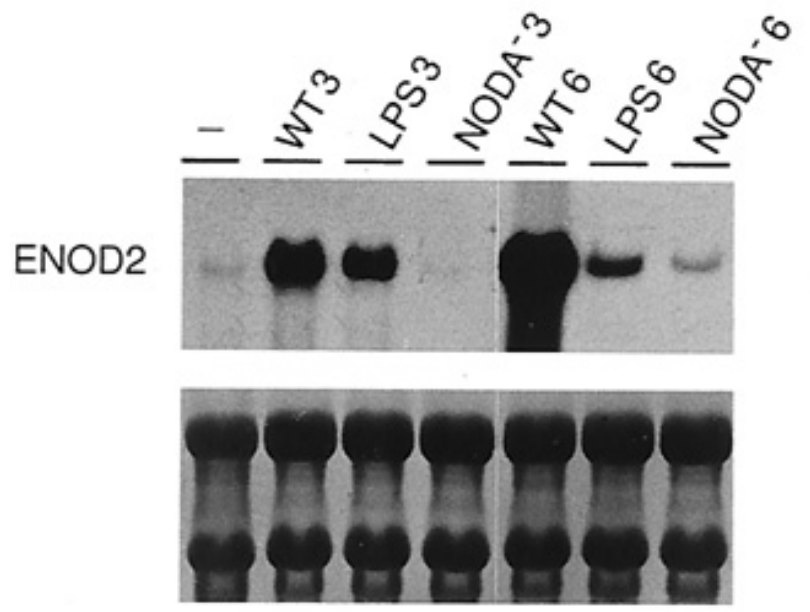

Fig. 3. ENOD2 expression upon inoculation with Azorhizobium caulinodans mutants. Transcript levels were investigated by RNA blot analysis in uninfected root primordia $(-)$ and primordia infected with wildtype A. caulinodans ORS571 (WT3, WT6), the mutant ORS571-X15 (surface polysaccharide mutant defective in invasion; LPS3, LPS6), and the mutant ORS571-V44 NodA $^{-}$, deficient in Nod factor production; $\mathrm{NODA}^{-3}$, NODA $\left.{ }^{-6}\right) 3$ and 6 days after infection. Filter was stained with methylene blue to confirm equal loading (lower panel). ter strain to the plant results in the formation of small, bacteria-free, nodulelike structures (Van den Eede et al. 1987).

RNA was isolated from uninfected and infected root primordia 3 and 6 days after inoculation with either bacterial strain. The ENOD2 RNA levels were visualized by RNA blot analysis as described before (Goormachtig et al. 1995). As shown in Figure 3, inoculation with ORS571-X15 resulted in an accumulation of ENOD2 transcripts, be it at a lower level and in a more transient way than after wild-type inoculation. On the other hand, no enhancement of transcript accumulation was observed after infection with ORS571-V44, implying that Nod factors may be the direct or indirect trigger for both ENOD2 accumulation patterns. The lower levels of expression seen after ORS571-X15 infection corresponded to the arrest in nodule development because of the inability of the strain to invade the root primordia. This result was confirmed by in situ hybridization, showing that the expression in the exterior cortical cells was not changed, compared with wild-type infection, but that the nodule parenchyma development and concomitant ENOD2 expression were blocked at a very early stage (data not shown).

As ENOD2 transcript accumulation in $S$. rostrata was shown to be cytokinin induced (Dehio and de Bruijn 1992), changes in transcript accumulation patterns may reflect local changes in cytokinin levels. The putative ENOD2 protein has been proposed to play a role in establishing an oxygen barrier (Witty et al. 1986) by determining the morphology of the parenchymatous cells (Van de Wiel et al. 1990). In the light of this hypothesis, expression in the exterior cortical cells could reflect a function for ENOD2 in constructing an oxygen barrier in the root primordium. Indeed, aerial roots and nodules are exposed to higher concentrations of oxygen than are roots and root nodules in the soil, and an oxygen barrier may be needed for root development. However, direct proof of a role for ENOD2 in constructing the oxygen barrier is not yet available. By comparing oxygen changes and ENOD2 accumulation in wild-type and in transgenic alfalfa plants with a lower $E N O D 2$ level, evidence was actually provided for the contrary (Hunt et al. 1995). Moreover, accumulation of ENOD2 transcripts was found in mycorrhizal alfalfa roots, a symbiotic system where an oxygen barrier was not reported (van Rhijn et al. 1997). The presence of ENOD2 in the cortical cells between the different nodule lobes and the peridermal cells also does not support the oxygen barrier hypothesis. Another proposed function for proline-rich proteins is to provide structural support to cells by reinforcements of cell walls (Showalter 1993; Josè and Puigdomènech 1993). Such a role would be plausible for ENOD2 given the mechanical stress that is most probably imposed on the nodule parenchyma and interlobal tissues by the enlargement of the central nodule tissue. Moreover, in the outer cortical cells, ENOD2 (as the adjacent suberized cells) could help to protect the incipient roots or stem-borne nodules against dehydration and other damaging agents. A better understanding of the meaning of the ENOD2 transcript accumulation patterns may be obtained by additional studies on protein localization.

\section{ACKNOWLEDGMENTS}

We thank Frans De Bruijn for providing the SrEnod2 clone, Sylvia Herman for technical assistance, Martine De Cock for help in preparing 
the manuscript, and Karel Spruyt, Christiane Germonprez, and Rebecca Verbanck for artwork. This work was supported by grants from the Belgian Programme on Interuniversity Poles of Attraction (Prime Minister's Office, Science Policy Programming, No. 38) and in part by the European Communities' BIOTECH Programme, as part of the Project of Technological Priority 1993-1996. M. H. is a Research Director of the Fund for Scientific Research (Flanders).

\section{LITERATURE CITED}

Allen, T., Raja, S., and Dunn, K. 1991. Cells expressing ENOD2 show differential spatial organization during the development of alfalfa root nodules. Mol. Plant-Microbe Interact. 4:139-146.

Chen, R., and de Bruijn, F. J. 1995. Regulation and function of the Sesbania rostrata early nodulin gene ENOD2. Page 502 in: Nitrogen Fixation: Fundamentals and Applications, (Current Plant Science and Biotechnology in Agriculture, Vol. 27), I. A. Tikhonovich, N. A. Provorov, V. I. Romanov, and W. E. Newton, eds. Kluwer Academic Publishers, Dordrecht, The Netherlands.

Dehio, C., and de Bruijn, F. J. 1992. The early nodulin gene SrEnod2 from Sesbania rostrata is inducible by cytokinin. Plant J. 2:117-128.

Duhoux, E. 1984. Ontogénèse des nodules caulinaires du Sesbania rostrata (légumineuses). Can. J. Bot. 62:982-994.

Franssen, H. J., Nap, J.-P., Gloudemans, T., Stiekema, W., van Dam, H., Govers, F., Louwerse, J., van Kammen, A., and Bisseling, T. 1987. Characterization of cDNA for nodulin-75 of soybean: A gene product involved in early stages of root nodule development. Proc. Natl. Acad. Sci. USA 84:4495-4499.

Franssen, H. J., Thompson, D. V., Idler, K., Kormelink, R., van Kammen, A., and Bisseling, T. 1989. Nucleotide sequence of two soybean ENOD2 early nodulin genes encoding Ngm-75. Plant Mol. Biol. 14: 103-106.

Franssen, H. J., Vijn, I., Yang, W. C., and Bisseling, T. 1992. Developmental aspects of the Rhizobium-legume symbiosis. Plant Mol. Biol. 19:89-107.

Goethals, K., Leyman, B., Van den Eede, G., Van Montagu, M., and Holsters, M. 1994. An Azorhizobium caulinodans ORS571 locus involved in lipopolysaccharide production and nodule formation on Sesbania rostrata stems and roots. J. Bacteriol. 176:92-99.

Goormachtig, S., Alves-Ferreira, M., Van Montagu, M., Engler, G., and Holsters, M. 1997. Expression of cell cycle genes during Sesbania rostrata stem nodule development. Mol. Plant-Microbe Interact. 10: 316-325.

Goormachtig, S., Valerio-Lepiniec, M., Szczyglowski, K., Van Montagu, M., Holsters, M., and de Bruijn, F. J. 1995. Use of differential display to identify novel Sesbania rostrata genes enhanced by Azorhizobium caulinodans infection. Mol. Plant-Microbe Interact. 8:816-824.
Hunt, S., Wycoff, K. L., Layzell, D. B., and Hirsch, A. M. 1995. Is the early nodulin ENOD2 associated with regulation of nodule permeability to oxygen? Page 504 in: Nitrogen Fixation: Fundamentals and Applications, (Current Plant Science and Biotechnology in Agriculture, Vol. 27), I. A. Tikhonovich, N. A. Provorov, V. I. Romanov, and W. E. Newton, eds. Kluwer Academic Publishers, Dordrecht, The Netherlands.

Josè, M., and Puigdomènech, P. 1993. Structure and expression of genes coding for structural proteins of the plant cell wall. New Phytol. 125: 259-282.

Long, S. R. 1996. Rhizobium symbiosis: Nod factors in perspective. Plant Cell 8:1885-1898.

Mergaert, P., Van Montagu, M., Promé, J.-C., and Holsters, M. 1993. Three unusual modifications, a D-arabinosyl, an $N$-methyl, and a carbamoyl group, are present on the Nod factors of Azorhizobium caulinodans strain ORS571. Proc. Natl. Acad. Sci. USA 90:1551-1555.

Showalter, A. M. 1993. Structure and function of plant cell wall proteins. Plant Cell 5:9-23.

Silver, D. L., Pinaev, A., Chen, R., and de Bruijn, F. J. 1996. Posttranscriptional regulation of the Sesbania rostrata early nodulin gene SrEnod2 by cytokinin. Plant Physiol. 112:559-567.

Strittmatter, G., Chia, T.-F., Trinh, T. H., Katagiri, F., Kuhlemeier, C., and Chua, N.-H. 1989. Characterization of nodule-specific cDNA clones from Sesbania rostrata and expression of the corresponding genes during the initial stages of stem nodules and root nodules formation. Mol. Plant-Microbe Interact. 2:122-127.

Tsien, H. C., Dreyfus, B. L., and Schmidt, E. L. 1983. Initial stages in the morphogenesis of nitrogen-fixing stem nodules of Sesbania rostrata. J. Bacteriol. 156:888-897.

Van de Wiel, C., Scheres, B., Franssen, H., van Lierop, M.-J., van Lammeren, A., van Kammen, A., and Bisseling, T. 1990. The early nodulin transcript ENOD2 is located in the nodule parenchyma (inner cortex) of pea and soybean root nodules. EMBO J. 9:1-7.

Van den Eede, G., Dreyfus, B., Goethals, K., Van Montagu, M., and Holsters, M. 1987. Identification and cloning of nodulation genes from the stem-nodulating bacterium ORS571. Mol. Gen. Genet. 206: 291-299.

van Kammen, A. 1984. Suggested nomenclature for plant genes involved in nodulation and symbiosis. Plant Mol. Biol. Rep. 2:43-45.

van Rhijn, P., Fang, Y., Galili, S., Shaul, O., Atzmon, N., Wininger, S., Eshed, Y., Lum, M., Li, Y., To, V., Fujishige, N., Kapulnik, Y., and Hirsch, A. M. 1997. Expression of early nodulin genes in alfalfa mycorrhizae indicates that signal transduction pathways used in forming arbuscular mycorrhizae and Rhizobium-induced nodules may be conserved. Proc. Natl. Acad. Sci. USA 94:5467-5472.

Witty, J. F., Minchin, F. R., Skøt, L., and Sheely, J. E. 1986. Nitrogen fixation and oxygen in root nodules. Oxf. Surv. Plant Mol. Cell Biol. $3: 275-315$. 